\begin{tabular}{lc|}
\hline UAD & ADJES (Ahmad Dahlan Journal of English Studies) \\
VOL 8, No. 1, 68-82 \\
$\begin{array}{l}\text { Universitas } \\
\text { Ahmad Dahlan }\end{array}$ \\
https://doi.org/10.26555/adjes.v8i1.20108
\end{tabular}

\title{
University Students' Willingness to Communicate in Virtual Classroom
}

\author{
${ }^{1}$ Hanifah, ${ }^{2}$ Elsa Ernawati Nainggolan \\ Email: 1hanifah@umrah.ac.id, 2elsanainggolan@umrah.ac.id \\ 1,2Universitas Maritim Raja Ali Haji, Tanjungpinang, Indonesia
}

\section{ARTICLE INFO}

Article history

Received: 23 February 2021

Revised: 15 March 2021

Accepted: 16 March 2021

Keywords

university students

willingness to communicate

virtual class

\section{ABSTRACT}

Shifting from real classes to online classes ideally does not decrease students' willingness to communicate (WTC) in a language classroom since it is an indication of successful language learning in a virtual class. Given the crucial of promoting students' willingness to communicate in English online class, the present study analyzed the patterns of university students' WTC in a synchronous virtual class. With this purpose in mind, 43 students taking English for general purposes were chosen as the sample in this study. To gather the data of students' WTC patterns, the online class using zoom application was observed by administrating the Coding scheme developed by Chao and Philp. The patterns of the students' WTC were analyzed and classified into six categorizes based on the scheme. The results of the study reveal that the occurrences and patterns of students' WTC are affected by different task types given by the lecturer. Thus, it is expected that education practitioners construct virtual learning design providing various activities so that students' WTC in an online classroom can be triggered and enhanced.

This is an open access article under the CC-BY-SA license.

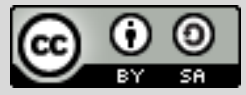

\section{Introduction}

Enhancing learners' communicative competence in language classroom activities is one of the crucial purposes in the second language (hereafter as L2) education. Accordingly, learners' involvement in classroom interaction is significant. In Indonesian, the consciousness to speak up and practice in classroom oral sessions is acknowledged yet unsuccessful effort to engage in classroom interaction is considered the problem of Indonesian learners (Abrar, Habibi, Asyrafi, and Marzulina, 2018). It interprets that the learners require opportunities to participate and elevate their communicative competence. In this regard, the facilitators, teachers demand to create practical learning situation to trigger learners' willingness to practice the target language in classroom interaction.

The study of WTC has conducted in various discourses as it can be found out in the literature. 
In the first language context, McCroskey and Bear (1985) initially proposed the concept of WTC as "the personality orientation which explains why one person will communicate and another will not under identical or virtually identical situational constraints". Further, MacIntyre, Dörnyei, Clément, and Noels (1998) developed a related study of WTC in the second language context and defined it as "a readiness to enter into discourse at particular time with a specific person or persons, using an L2". Both of the contexts are different because WTC in the L2 context is more complicated rather than the L1 context by considering some factors such as socialpsychological, classroom, cultural, and social-individual context. (Pattapong, 2015)

MacIntyre, et al. (1998) initiate a heuristic model consist of various factors that potentially influence WTC in L2. The interrelations among the categories are presented in a pyramid-shaped structure. The structure describes the complexity of the L2 use concept and explains WTC as cognitive-affective variables interacting with social factors. It represents six layers, layers I, II, and III refer to situational influences, and layers IV, V, VI refer to enduring influences. Depicting the hierarchy of the pyramid, the top of the pyramid (communication behavior) is the most immediate situational and transient influence on L2 communication situations while the bottom of the pyramid (personality and inter-group climate) is the least immediate situational and transient influence on L2 communication situations.

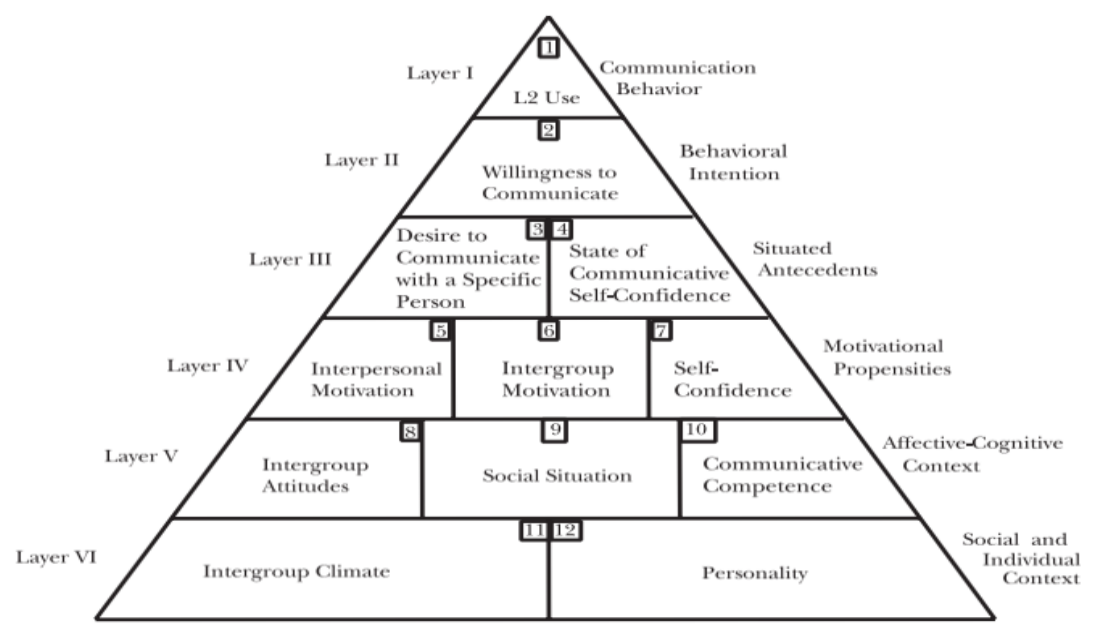

Figure 1. Heuristic model of variable influencing WTC

The studies addressing WTC in the classroom environment have been extensively discussed in recent years. One of the studies was conducted by Khatib \& Nourzadeh (2015), they considered six components in instructional WTC: communicative self-confidence, integrative orientation, the situational context, topical enticement, learning responsibility, off-instruction communication. In addition, other studies found several factors that influence students' WTC such as teachers' attitude and involvement (Cao, 2011; Cao \& Philp, 2006; Zarrinabadi, 2014), teacher's strategy (Lee \& Ng, 2010), teacher's teaching methods (Zacharias, 2014) task orientation (Peng \& Woodrow, 2010) task types (Khatibi \& Zakeri, 2014) and interlocutor 
factors (Kang, 2005). As a matter of fact, the previous studies show that WTC in the classroom environment not only influence by the students' factors, but the teachers' factors are also crucial in shaping students' willingness to participate in classroom activities. When the students have enough information or background knowledge about the learned topics, the students likely are more willing to share their ideas. Moreover, the students will also be more willing to participate when the teacher facilitates the students and promote clear instruction for the task.

With the sudden shift away from offline to online learning in the pandemic era, the teachers and students are impacted in many aspects during classroom activities. One of the effects is faceto-face classes switch into online classes in which learning processes are conducted using several applications or learning platforms such as group chat, digital classes, and video call. In this case, the teachers are required to determine the appropriate platforms by considering the learning purpose and students' condition. Meanwhile, the students are forced to move away from their old learning practices in real activities into virtual ones where they experience virtual presentation, discussion, and participation. Given the fact that online class has been changed the classroom environment, it is assumed that the students will have different tendency to involve in virtual communication during classroom activities.

As noted earlier, there are lots of studies that tried to find out the WTC in real classroom interaction. However, further research is needed in another worthwhile direction in foreign language WTC research (Havwini,2019) and research on online classroom is crucial in pandemic era. Hence, more explanations are needed about whether the virtual classroom's interaction may meet the goals to promote students' engagement, especially in communication. This study delves deeper into students' WTC in online classes; specifically, in what patterns the EFL students at the university level applied WTC in their spoken communication. As the matter of fact, some applications in virtual classless are used to conduct synchronous learning and others are purposed for asynchronous learning. In line with the aim of this study, it only investigates students' WTC in video call activities (synchronous learning) using zoom application. It is expected that this study contributes to further efforts of the lecturers to enhance students' WTC in EFL online classes, as it will help the lecturers to then prepare virtual activities that may trigger students' participation.

\section{Method}

There are 43 students from English Department at Universitas Maritim Raja Ali Haji were observed. They are taking English for general purposes in the first semester that conducted virtually. They experienced virtual lectures for the first time and required them for using various online learning platforms. Most of them were able to use the platforms especially zoom. 
The only problem they faced during the virtual class was the internet connection. They were learning grammar and the four language skills in English subject: listening, speaking, reading, and writing skills. In terms of English proficiency, the students had different ability; it can be seen from their self-evaluation at the beginning of the semester.

The study is designed as a naturalistic study because the data were gathered from observation in regular circumstances (Frey, Botan, \& Kreps, 2000). The observation conducted during 4 virtual meetings using zoom application. The students' WTC analyzed from the recording of instructional practices during the meetings. From the total 400 minutes duration of the observed meetings, the researcher selected two meetings to be transcribed verbatim and analyzed. The selected meetings were considered representative because the instructional strategies were overall similar where the learning activities showed interaction among the students and lecturer during classroom discussion. To analyze the students' WTC pattern found during zoom meeting interaction, the researcher deployed a coding scheme adapted from Chao and Philp (2006) in Havwini (2019) with some necessary changes and additions to fit the present study need. This scheme recognizes the following patterns: (Pattern 1) volunteering answers to the teacher's questions, (Pattern 2) asking the teacher a question, (Pattern 3) presenting one's own opinion in the class, (Pattern 4) volunteering participation in class activities, (Pattern 5) giving comments or questions in response to peer's ideas, and (Pattern 6) helping peers to recall difficult or forgotten words. The data gathered from the selected videos were organized, identified, and categorized based on the scheme used.

\section{Discussion}

This research examined students' WTC in English language education study program conducted using zoom, particularly the pattern applied during oral communication. Using a coding scheme adapted from Cao and Philp (2006), the students' WTC patterns were identified. The percentage of students' WTC patterns found in the observed meeting is portrayed in table 1 below:

Table 1. The percentage of students' WTC Patterns

\begin{tabular}{|c|c|}
\hline Core Critical Thinking Skill & Percentage \\
\hline Pattern 1 & $41 \%$ \\
\hline Pattern 2 & $17 \%$ \\
\hline Pattern 3 & $17 \%$ \\
\hline Pattern 4 & $13 \%$ \\
\hline Pattern 5 & $7 \%$ \\
\hline Pattern 6 & $1 \%$ \\
\hline
\end{tabular}

As shown in table 1, the highest percentage of the students' WTC is pattern 1 (volunteering answers to the teacher's questions) and the lowest percentage is pattern 6 (helping peers to recall difficult or forgotten words). The percentage of pattern 1 is $41 \%$, pattern 2 (asking the 
teacher a question) in $17 \%$, pattern 3 (presenting one's own opinion in the class) is $17 \%$, pattern 4 (volunteering participation in class activities) gets 13\%, pattern 5 (giving comments or questions in response to peer's ideas) gains $7 \%$ and pattern 6 is 1\%. Each pattern of students' WTC that occurred during the meetings is discussed in reference to the theory proposed by experts as follows. The discussion is presented by elaborating the finding from the highest to the lowest percentages.

\section{1. (Pattern 1) Volunteering Answers to the Lecturer's Questions}

This pattern appeared when the teacher started the session by giving a question for all of the students or only for some of them. The question addressed to the whole class was responded quickly by certain students. However, the question gave to a specific group or individual took a long time to be responded. The excerpt of the conversation is presented below:

Excerpt 1

L: Before we start our lesson, I want to ask you some questions. I believe that all of you have a mobile phone. What happens if your mobile phone is lost or broken? What do you feel?

S1: Feel sad of course miss

S2: Looking for it all day

S3: I will confuse miss

S4: It feels lonely aaa I think everything I am gonna access is from the phone: lesson, friends' number, social media, e-banking, shopping, game. So, I am gonna feel lonely I think

L: It's interesting.

As illustrated in Excerpt 1, the conversation occurred at the beginning of the lesson. It was situated when the lecturer began the session by giving some questions. The lecturer's questions aimed to grab students' attention and lead the students to the topic. The topic in that meeting was technology and the skill that the class focus on was speaking. For that purpose, the teacher chose the open-ended question which provides a possibility to give a short or long answer. Given the fact that is easy to a give simple answer to this question, the students had more confidence to state their opinion. Excerpt 1 shows that some students respond to the question in simple sentences and only a student adds the explanation and gives a long answer.

Excerpt 2

L: Then, what will you do if your phone is lost or broken?

S1: I fix it as soon as possible

S2: Buy new phone 
S3: Maybe I will be angry miss

S4: may I answer that question miss

S5: Let me miss

S4: me miss

L: Gantian (take a turn). Ok let me chose one, Siti Aisyah

S5: I want the latest Samsung cell phone because of the good quality of the camera and battery but I know it's very expensive

The conversation in excerpt 2 illustrates how the students enthusiastically answer the lecturer's question. The excerpt shows that the lecturer invites the students to share their ideas by asking a question that closes to their personal experience or daily lives. Many students wanted to state their answers although not all of their answers were right. At that time, the lecturer controlled the class and pointed out one student to speak up in order to make sure the answer was appropriate grammatically and reasonable.

Excerpt 3

L: My question, how many speakers in this conversation?

S: Aaaa....(silent for a moment) just two miss

L: Who are they?

S: I don't know the name of the boys... speakers.

Previously, the lecturer shared a video and gave the students time for watching the video. Then, the students were given a chance to retell the video using their own sentences. The conversation above occurred when one of the students finished his presentation and the lecturer asked a question to check his understanding. It can be said that this conversation different from the two preceding conversations since in this conversation only one student involved and the question addressed directly to that student. Before answering, the students took a moment and seemed uncertain about his answer.

Excerpt 4

L: How about the boys, what do you feel?

S: I think it's not really important and just so-so. But if I lost someone important, I will stress, depression

This conversation occurred when the lecturer noticed that there was no boy participated in the activity. Then, the lecturer invited the boys to engage in the discussion and share their answers. After some time, a male student clicked a raised hand emoticon and started to speak up. In the same with the previous conversation, the excerpt shows that only a student involved in the conversation however the question was intended for a certain group (male students). This situation represents that when the lecturer addressed the question to certain group, it would 
need more time for the students to prepare the answer.

\section{2. (Pattern 2) Asking the Lecturer a Question}

This pattern was found to be the second most frequent WTC pattern which appeared during the observation. The percentage of pattern 2 is 19 . This pattern was observed mainly when the students wanted to confirm their understanding of certain words or confirm the lecturers' instruction.

\section{Excerpt 5}

S1: Miss when we use the word message and when we use the word text

L: They have the same meaning, so you can use both of them in the same context. For example: Send me a message/text when you want to come to my house

The conversation occurred when discussing new vocabularies where the lecturer mentioned some new English words and asked the students to guest the synonym or the meaning. In excerpt 5, a student asked a question about the context to use the two words. Instead of giving an opportunity for other students to answer the question, the lecturer directly mentioned the answer and made a sentence that used the two words in purpose to show the context when the words could be used.

Excerpt 6

S1: Can I do the conversations alone Miss, I ask myself and answer it by myself?

L: It's up to you...

S1: Maksudnya miss (what do you mean miss?)

S2: Ooo...we can do it alone or with friends, right miss?

L: yes

In excerpt 6, a student asked about the lecturer's instruction to do an exercise. The student asked the question in order to confirm her perception. The lecturer responded to the students' question but in the middle of the lecturer's explanation, the student switched her language into Bahasa and asked another question indicating she was still confused. In the next turn, another student tried to help and share her opinion.

Excerpt 7

L: Next?

S: What if I have more than two sentences?

L: It's ok

S: The phone have three cameras, the camera can night mode

L: has not have 
The conversation in excerpt 7 is another illustration of students' WTC in pattern 2. It occurred in a presentation session where a student retold a video to the whole class. Before presenting, a student asked a question that indicated he wasn't really sure to convey his ideas but still curious to present the ideas. Observing his presentation, the student was weak in grammar and made many mistakes in his presentation. However, the student had willing to present his ideas. It illustrates that some students with low ability in grammar and speaking need encouragement to motivate them to speak up. They have opportunities to learn from their mistake during a presentation as can be seen in the last turn in the conversation.

\section{3. (Pattern 3) Presenting One's Own Opinion in the Class}

As displayed in table 2, the percentage of this pattern is $17 \%$. It places pattern 3 equal to pattern 2. It indicates that many students paid attention to the lesson and had the desire to present their own opinion in the class. The students' excerpts are provided below.

Excerpt 8

S: My favorite cell / kel/ phone is Iphone because it have better quality than other phone such as it has larger memory to accommodate a lot of data.

L: Nice try. But it is not / kel/ but/Sel /, pakai has bukan have (use has instead of have)

S: /sel/

L: yes, that's it.

S: My favorite cell phone is Iphone because it has better quality than other phone such as it has larger memory to accommodate a lot of data.

The excerpt above shows that a student states her opinion voluntarily. The student made pronunciation and grammar mistakes while conveying her sentence. The lecturer appreciated her for her courage to express her idea. The lecturer also corrected her mistakes after she finished her sentence. Then, the student directly corrected her pronunciation and repeated her sentence.

\section{Excerpt 9}

L: I see someone raise hand, it's your turn.

S1: Ok, thank you for the occasions miss. I want Oppo mobile hmm... has so many variations.

S2: Yes miss, me too. I want Oppo. The camera is good. I need it for selfie.

The conversation in except 9 occurred when the lecturer asked the students to give their opinion about a picture. One of the students used raised hand emoticon and wait for a chance given to speak up. As can be seen in excerpt 9, there are two students involved in the conversation. The first student said a simple sentence and missed the connection between the phrases. Then, the second student immediately added her idea that supported the previous idea. 


\section{Excerpt 10}

S: In my opinion, this video is about someone that wants to change his cell phone because it has already been using for a year. Actually, the used time is not a problem. The problem he needs a smart phone now. But he didn't know which model he plans to buy.

L: Ok. Good.

In excerpt 10, the students watched a video then had some time to prepare their selves to retell the video to their friends. The student used raised hand to indicate that he wanted to participate. He explained the video simply and clearly. For his participation, the lecturer gave a compliment.

\section{4. (Pattern 4) Volunteering Participation in Class Activities}

The percentage of this pattern is $13 \%$. The students volunteered in some activities: writing sentences in the chat box, reading some sentences, retell a video, and creating their own sentences. The participations included in this pattern are initiated by the students before the lecturer instructing the students to do the activities.

\section{Excerpt 11}

S: My sentence: The phone has good quality camera. It has three back cameras that is good resolution to take photo or video. The type is the latest version from the brand. I have three sentences miss. Sorry miss.

L: I said it is ok if you have more than two sentences.

S: I will write down the sentences in the chat box.

L: Good idea then your friend can see it.

As can be seen in excerpt 11, a student made some sentences about a picture given by the lecturer. There only two sentences were required but she created three sentences. It seemed she already prepared for it. She expressed the sentences fluently and clearly. After saying the sentences, she initiated to write down the sentences in the chat box then other students could see them and avoid repeating the same sentences. The lecturer appreciated her idea and let her write the sentences.

\section{Excerpt 12}

S1: I want to read the second sentence miss. The phone rang and everybody stare at it. Then Maria slowly picks it up.

L: What the synonym of pick it up guys?

S2: Take. 


\section{S3: Answer.}

S4: Memungut miss

The conversation in excerpt 12 occurred when the lecturer showed the students some sentences in the chat box. The students would find the synonym of an unknown word in the given sentences. As shown that the students participated actively in this session. The first students in the first turn suddenly volunteered to read a sentence given by the lecturer. Other students answered the lecturer's question about the synonym of a word. They gave different answers and one of them used Bahasa and tried to translate the English word.

\section{Excerpt 13}

S: Can I retell the video now miss?

L: yes please.

S: I'm sorry before because I answer just with my opinion, if it's wrong please correct me miss. From the video I show that sham want to buy a new smart phone because he is using his phone already more than a year, then he asks Jane what kind of phone he should buy, it's android or Iphone. Then Jane said her brother has iPhone so Same choosing to buy I phone 5 because it's new model and slime and with 8 mega pixel camera. Then, Same ask to Jane again how to use the app store, then Jane said app store just browsing what you want then explore that. Some app with paid app and some other is free. That's it, Miss. Thank you.

In excerpt 13 , the students watched a video then had some time to prepare their selves to retell the video to their friends. At that time when the lecturer was waiting for the students to get ready, suddenly a student initiated to retell a video given by the lecturer. Actually, some other students used the raise hand emoticon to take turns retelling the video.

\section{5. (Pattern 5) Giving Comments or Questions in Response to Peer's Ideas}

The percentage of pattern 5 is 7\%. This pattern was infrequent appeared in the conversation. It was observed mainly when the students asked a question to confirm their friends' answers. Whereas, there is only one conversation which shows a student gave compliment for his friend's performance. The excerpt below illustrates the occurrence of pattern 5 .

\section{Excerpt 14}

L: what do you think the meaning of hang up in this sentence?

\section{S1: mengangkat miss}

S2: I think it's not mengangkat but tidak mengangkat atau mematikan

S3: which one is correct miss?

L: Anyone can help? 
S2: tidak mengangkat miss

L: Ok

In Excerpt 14 there are three students involved in the conversation. The conversation began when the lecturer checked the students' understanding of a phrase of verb. The first student gave the wrong answer and said the contrasting meaning. The second student corrected her friend's answer and said the rights answer. In the next turn, the third student confirmed the correct answer from the two answers given and said "which one is the correct answer?" Responding to the question, the lecturer did not directly answer instead let other students give the answer.

Excerpt 14

L: Why do you clap your hand Didi?

S1: Her performance is cool miss

S2: Haaa... tank you

Excerpt 14 is another illustration of the students' WTC in pattern 5. It is the only conversation shows the students gave compliment (comment) for other students' performance. In the first turn, the lecturer asked the first student because he posted a clap emoticon. Then, the first student explained that he posted the emoticon because he loved his friend's performance and expressed it with the emoticon. Receiving the compliment from her friend, the second student responded and said thank you.

\section{6. (Pattern 6) Helping Peers to Recall Difficult or Forgotten Words}

This pattern was found to be the least frequent students' WTC that appeared during the observation. The percentage of pattern 6 is $1 \%$. This pattern was observed only one time during the conversation. Based on the classroom observation, it can be stated that this pattern infrequently appeared since during the learning activities the students mostly used their time for presentation. Meanwhile, the lecturer had provided enough time for the students to prepare it. Accordingly, the students had a chance to check dictionary before their presentation and most of the students could convey their idea nicely. The excerpt of this pattern can be seen below.

\section{Excerpt 15}

S1: Ok, Sam wants to buy a new phone because his old phone is too old for this era. So, he ask the woman to recommendation to his phone

L: recommend

S1: So she gives recommendation to ....

S2: to buy Iphone 
S: yes, to buy Iphone

Based on the finding from the students' conversations, it can be stated that "volunteering answers to the lecturer's questions" (pattern 1) is the most frequently appeared in the conversations. This finding implied that asking the students question is a good strategy to stimulate and make students actively participate in classroom interaction. It can be seen that the lecturer made use of the strategy on many occasions. The lecturer used various types of questions for different purposes. Ummah (2016) in her research has discovered that many types of questions can be delivered depending on the competencies required in every class session. The types of questions that can be used in the classroom activities namely, yes/no questions, short answer questions, display questions, open-ended questions, referential questions, and nonretrieval questions Wanjryb (1992). It thus suggests that students will likely more willing to involve in classroom communication when the lecturer takes their role as a facilitator in the learning process and facilitate the students to discover the occasion to contribute to classroom communication. Then, it also requires the lecturer to facilitate the students with appropriate questions to improve their language skills. Another pedagogical implication of this finding is in line with an earlier study conducted by Havwini (2019), the more the questions are related to the students' life, and the more the students are enthusiastic to give responses. This result raises a suggestion that the lecturer can increase students' WTC by relating the topic to students' daily lives.

In addition, it was identified that the virtual classes and the platform used (zoo) did not become an obstacle for the students and lecturer to communicate during the lesson. This finding is in line with Rahayu (2020) who stated that zoom is a real-time live web-conference platform where the participants can experience to communicate and give questions or answers at ease during the study process. Moreover, it was also observed that zoom gave some advantages for the students to express their willingness to communicate not only in verbal but also in nonverbal ones. It assists students to take a queue to speak up by means of a raise hand emoticon and it helps students to show their appreciation to others using clap emoticon. This idea supported by Maryansyah (2019) who stated that WTC is not limited to verbal language. Then, it can be said that students who clicked raise hand menu when they wanted to get a chance to answer questions are an example of WTC as it is a sign that they intend to communicate.

Meanwhile, the existence of Pattern 6 (helping peers to recall difficult or forgotten words) becomes the least frequently appeared in the classroom conversation. Although this pattern is only found once, it does not mean that the students do not have willingness to communicate with their friends. This situation happened since the learning activities have been designed to take more time for preparing and doing presentations. Therefore, the students are able to convey 
their ideas well enough and it is not necessary to recall some vocabularies during their presentation. It can be indicated that each learning design has different concern and require certain feedback from the students, so if the students are expected to interact more, the activities provided can be group work or peer work. As suggested by Adam (2018), working with a language learner peer makes the learners talk more to maintain a conversation, try new vocabularies and forms to deliver the meanings, help each other to correct mistakes, and solve problems when they get stuck in the communication.

\section{Conclusion}

Students' willingness to communicate has been observed in a virtual English class at the university level. The findings show that the students express their WTC not only in verbal but also in non-verbal language. Verbal WTC most frequently observed when the students answer the lecturer's questions. It can be stated that giving students questions is a practical strategy that strongly triggers students' WTC. In this study, the lecturer variegates the questions in each learning stage. The students are also encouraged to elaborate their answers by giving more time for preparing their performances; as a result, the students are more willing to participate in the speaking activities. However, students' WTC to interact with their friends infrequently found in this study since the learning design resulting in lecturer and learner's interaction take more places. Moreover, non-verbal WTC is identified when the students make use of some emoticons provided by zoom such as raise hand and clap. It can be concluded that virtual classes are not an obstacle for the learners to express language. As a matter of fact, it does not discourage the learners to show their willingness to communicate.

Based on this study, it is suggested that lecturers endeavor optimizing the appropriate strategies to improve students' participation, especially in virtual classroom. Encouraging interaction among the students and providing collaborative activities should be a consideration in order to face the student's other communication setting and evoke more WTC patterns. In regard to future research, examining students' WTC in virtual classes using different platform and teaching strategies is recommended.

\section{References}

Abrar, M., Mukminin, A., Habibi, A., Asyrafi, F., \& Marzulina, L. (2018). " If our English isn't a language, what is it?" Indonesian EFL student teachers' challenges speaking English. The Qualitative Report, 23(1), 129-145.

Adams, R. (2018). Enhancing student interaction in the language classroom: Part of the Cambridge 
Papers in ELT series. Cambridge: Cambridge University Press.

Cao, Y. (2011). Investigating situational willingness to communicate within second language classrooms from an ecological perspective. System, 39(4), 468-479. https://doi.org/10.1016/j.system.2011.10.016

Cao, Y., \& Philp, J. (2006). Interactional context and willingness to communicate: A comparison of behavior in whole class, group and dyadic interaction. System, 34(4), 480-493. https://doi.org/10.1016/j.system.2006.05.002

Fadilah, Eka. (2018). Willingness to communicate from Indonesian learners' perspective. Journal of ELT Research: The Academic Journal of Studies in English Language Teaching and Learning, 3(2), 168-185. https://doi.org/10.22236/JER_Vol3Issue2pp168-185

Frey, L., Botan, C. H., \& Kreps, G. (2000). Investigating communication. NY: Allyn \& Bacon.

Havwini, T. (2019). Indonesian EFL students' willingness to communicate in the 2013 curriculum implementation: A case study. TEFLIN Journal, 30(1), 105-120. https://doi.org/10.15639/teflinjournal.v30i1/105-1

Kang, S.-J. (2005). Dynamic emergence of situational willingness to communicate in a second language. System, 33(2), 277-292 https://doi.org/10.1016/j.system.2004.10.00420

Khatib, M., \& Nourzadeh, S. (2015). Development and validation of an instructional willingness to communicate questionnaire. Journal of Multilingual and Multicultural Development, 36(3), 266-283. https://doi.org/10.1080/01434632.2014.914523

Khatibi, M. B., \& Zakeri, J. (2014). Iranian EFL learners' willingness to communicate across different context-and receiver-types. Procedia-Social and Behavioral Sciences, 9(8), 932-939. https://doi.org/10.1016/j.sbspro.2014.03.502

Lee, W., \& Ng, S. (2010). Reducing student reticence through teacher interaction strategy. ELT Journal, 64(3), 302-313. https://doi.org/10.1093/elt/ccp080

McCroskey, J. C. \& Baer, J. E. (1985, November). Willingness to communicate: The construct and its measurement. Paper Presented at the Annual Meeting of the Speech Communication Association, Denver, Colorado.2-11

MacIntyre, P. D., Dörnyei, Z., Clément, R., \& Noels, K. A. (1998). Conceptualizing willingness to communicate in a L2: A situational model of L2 confidence and affiliation. The Modern Language Journal, 82(4), 545-562. https://doi.org/10.1111/j.1540-4781.1998.tb05543.x

Maryansyah, Y. (2019). A study on English students' willingness to communicate in English in social media. Premise: Journal of English Education, 8(1), 31-45. https://doi.org/10.24127/pj.v8i1.1930 
Pattapong, K. (2015). Complex interactions of factors underlying Thai EFL learners' willingness to communicate in English. PASAA: Journal of Language Teaching and Learning in Thailand, 49, 105-136.

Pawlak, M., Mystkowska-Wiertelak, A., \& Bielak, J. (2016). Investigating the nature of classroom willingness to communicate (WTC): A micro-perspective. Language Teaching Research, 20(5), 654-671. https://doi.org/10.1177/1362168815609615

Peng, J. E.,\& Woodrow, L. (2010). Willingness to communicate in English: A model in the Chinese EFL classroom context. Language Learning, 60(4), 834-876. https://doi.org/10.1111/j.14679922.2010.00576.x

Rahayu, D. (2020). Students' e-learning experience through a synchronous zoom web conference system. Journal of ELT Research, 5(1), 69-79. https://doi.org/10.22236/JER_Vol5Issue1pp6879

Ummah, K., Thaib, R., Saun, S. (2016). Types of questions asked by English teachers in teaching and learning process at SMA Pembangunan UNP Padang. Journal of English Language Teaching, 5(1), 325-330. https://doi.org/10.24036/jelt.v5i1.7331

Wanjryb, R. (1992).Classroom observation tasks. Cambridge: Cambridge University Press.

Zacharias, N. T. (2014). Second language teacher contributions to student classroom participation: A narrative study of Indonesian learners. ELTWorldOnline. com, 6, 1793-8732. 